\title{
Analysis of Stationary, Photovoltaic-Based Surface Power System Designs at the Lunar South Pole
}

Joshua E. Freeh

Glenn Research Center, Cleveland, Ohio 


\section{NASA STI Program . . . in Profile}

Since its founding, NASA has been dedicated to the advancement of aeronautics and space science. The NASA Scientific and Technical Information (STI) program plays a key part in helping NASA maintain this important role.

The NASA STI Program operates under the auspices of the Agency Chief Information Officer. It collects, organizes, provides for archiving, and disseminates NASA's STI. The NASA STI program provides access to the NASA Aeronautics and Space Database and its public interface, the NASA Technical Reports Server, thus providing one of the largest collections of aeronautical and space science STI in the world. Results are published in both non-NASA channels and by NASA in the NASA STI Report Series, which includes the following report types:

- TECHNICAL PUBLICATION. Reports of completed research or a major significant phase of research that present the results of NASA programs and include extensive data or theoretical analysis. Includes compilations of significant scientific and technical data and information deemed to be of continuing reference value. NASA counterpart of peer-reviewed formal professional papers but has less stringent limitations on manuscript length and extent of graphic presentations.

- TECHNICAL MEMORANDUM. Scientific and technical findings that are preliminary or of specialized interest, e.g., quick release reports, working papers, and bibliographies that contain minimal annotation. Does not contain extensive analysis.

- CONTRACTOR REPORT. Scientific and technical findings by NASA-sponsored contractors and grantees.

- CONFERENCE PUBLICATION. Collected papers from scientific and technical conferences, symposia, seminars, or other meetings sponsored or cosponsored by NASA.

- SPECIAL PUBLICATION. Scientific, technical, or historical information from NASA programs, projects, and missions, often concerned with subjects having substantial public interest.

- TECHNICAL TRANSLATION. Englishlanguage translations of foreign scientific and technical material pertinent to NASA's mission.

Specialized services also include creating custom thesauri, building customized databases, organizing and publishing research results.

For more information about the NASA STI program, see the following:

- Access the NASA STI program home page at http://www.sti.nasa.gov

- E-mail your question via the Internet to help@ sti.nasa.gov

- Fax your question to the NASA STI Help Desk at 301-621-0134

- Telephone the NASA STI Help Desk at 301-621-0390

- Write to: NASA Center for AeroSpace Information (CASI) 7115 Standard Drive Hanover, MD 21076-1320 


\title{
Analysis of Stationary, Photovoltaic-Based Surface Power System Designs at the Lunar South Pole
}

\author{
Joshua E. Freeh \\ Glenn Research Center, Cleveland, Ohio
}

Prepared for the

Space 2008 Conference and Exposition

sponsored by the American Institute of Aeronautics and Astronautics

San Diego, California, September 9-11, 2008

National Aeronautics and

Space Administration

Glenn Research Center

Cleveland, Ohio 44135 


\section{Acknowledgments}

The author would like to acknowledge Thomas W. Kerslake, NASA Glenn Research Center, for his efforts in the early lunar surface power system studies in support of ESAS and LAT and his mentoring and support for this effort; Joseph J. Nainiger, Alphaport, Inc., for his effort and collaboration during the LAT studies; James Fincannon, NASA Glenn Research Center, for support with the DEM data as well as his technical review of the paper; Patrick J. George, Robert L. Cataldo, and Jeffrey S. Hojnicki, NASA Glenn Research Center, for their technical reviews of the paper.

This report contains preliminary findings, subject to revision as analysis proceeds.

Trade names and trademarks are used in this report for identification only. Their usage does not constitute an official endorsement, either expressed or implied, by the National Aeronautics and Space Administration.

Level of Review: This material has been technically reviewed by technical management.

Available from

NASA Center for Aerospace Information 7115 Standard Drive

Hanover, MD 21076-1320
National Technical Information Service 5285 Port Royal Road Springfield, VA 22161 


\title{
Analysis of Stationary, Photovoltaic-Based Surface Power System Designs at the Lunar South Pole
}

\author{
Joshua E. Freeh \\ National Aeronautics and Space Administration \\ Glenn Research Center \\ Cleveland, Ohio 44135
}

\begin{abstract}
Combinations of solar arrays and either batteries or regenerative fuel cells are analyzed for a surface power system module at the lunar south pole. The systems are required to produce $5 \mathrm{~kW}$ of net electrical power in sunlight and $2 \mathrm{~kW}$ of net electrical power during lunar night periods for a 10-year period between 2020 and 2030. Systems-level models for energy conservation, performance, degradation, and mass are used to compare to various systems. The sensitivities of important and/or uncertain variables including battery specific energy, fuel cell operating voltage, and DC-DC converter efficiency are compared to better understand the system. Switching unit efficiency, battery specific energy, and fuel cell operating voltage appear to be important system-level variables for this system. With reasonably sized solar arrays, the regenerative fuel cell system has significantly lower mass than the battery system based on the requirements and assumptions made herein. The total operational time is estimated at about 10,000 hours in battery discharge/fuel cell mode and about 4,000 and 8,000 hours for the battery charge and electrolyzer modes, respectively. The estimated number of significant depth-of-discharge cycles for either energy storage system is less than 100 for the 10-year period.
\end{abstract}

\section{Nomenclature}

$\begin{array}{ll}V & \text { voltage, } \mathrm{V} \\ I & \text { current, } \mathrm{A} \\ P & \text { power, } \mathrm{W} \\ J & \text { current density, } \mathrm{A} / \mathrm{cm}^{2} \\ R & \text { resistance, } \Omega \\ T & \text { temperature, } \mathrm{K},{ }^{\circ} \mathrm{C} \\ A & \text { area, } \mathrm{m}^{2} \\ r & \text { radius, } \mathrm{m} \\ m & \text { mass, kg } \\ N & \text { number } \\ \dot{m} & \text { molar flow rate, mol } / \mathrm{s} \\ Q & \text { heat, W } \\ m f & \text { mass fraction } \\ \bar{m} & \text { mass per area, } \mathrm{kg} / \mathrm{m}^{2} \\ C_{1} & \text { solar array I-V curve term, from Rauschenbach }{ }^{1} \\ C_{2} & \text { solar array I- } \mathrm{C} \text { curve term, from Rauschenbach }{ }^{1} \\ f & \text { factor } \\ F & \text { Faraday's constant } \\ & \\ \frac{V_{o c}}{\Delta T} & \text { solar cell temperature coefficient for } V_{o c}, \mathrm{~V} /{ }^{\circ} \mathrm{C} \\ V_{m p} & \end{array}$


$\frac{J_{s c}}{\Delta T} \quad$ solar cell temperature coefficient for $J_{s c}, \mathrm{~A} /\left(\mathrm{cm}^{2 \circ} \mathrm{C}\right)$

$\frac{J_{m p}}{\Delta T} \quad$ solar cell temperature coefficient for $J_{m p}, \mathrm{~A} /\left(\mathrm{cm}^{2 \circ} \mathrm{C}\right)$

\author{
Subscripts \\ cell single cell \\ packing packing \\ $f c \quad$ fuel cell \\ $m p \quad$ maximum power \\ oc open-circuit \\ op operating \\ rad radiator \\ ref reference \\ $S A D A$ solar array drive assembly \\ $s c \quad$ short circuit \\ $\mathrm{H}_{2} \quad$ hydrogen \\ $\mathrm{O}_{2} \quad$ oxygen \\ $\mathrm{H}_{2} \mathrm{O}$ water \\ Greek Symbols \\ $\eta \quad$ efficiency/effectiveness \\ $\epsilon \quad$ emissivity \\ $\sigma \quad$ Stefan-Boltzmann constant \\ Abbreviations \\ BOL beginning of life \\ CIC coverglass/interconnect/cell \\ ESAS Exploration Systems Architecture Study \\ LAT Lunar Architecture Team \\ NASA National Aeronautics and Space Administration \\ PEM polymer electrolyte membrane \\ PMAD power management and distribution \\ RFC regenerative fuel cell \\ SADA solar array drive assembly
}

\title{
I. Introduction
}

In 2004, the President announced the Vision for Space Exploration, ${ }^{2}$ in which he detailed plans to develop the Crew Exploration Vehicle and return to the Moon and ultimately send humans to Mars. This announcement initiated several iterations of studies that are ongoing to evaluate how to get the Moon and what is necessary to sustain a human presence there. The first major study, the Exploration Systems Architecture Study (ESAS), established the initial designs for Orion, Ares I, Ares V, and Altair spacecraft as well as the beginning of the lunar surface systems studies. ${ }^{3}$ After the ESAS completed, the Lunar Architecture Team (LAT) was created to explore the surface architecture and its interactions with the transportation systems in more detail. The first iteration of the LAT studies focused on refining the ESAS results and was announced by NASA in December 2006. ${ }^{4}$ The second iteration of LAT studies expanded the options to include a cargo lander and a mobile lander design. Its results were presented at AIAA Space $2007^{5}$ and other forums. ${ }^{6,7}$ The LAT studies are ongoing and continue to both refine and expand the options in preparation for more detailed design efforts in the future. The latest results were presented in support of a milestone entitled the Lunar Capability Concept Review in June $2008^{8}$ and at other meetings as well. ${ }^{9}$ NASA has also emphasized the opportunity for international and commercial partnerships in the lunar surface architecture. ${ }^{10}$ 


\section{Illumination at the Lunar South Pole}

Establishing a permanent human presence on the Moon introduces significant challenges beyond that of the Apollo missions, which stayed no longer than about 75 hours on the surface. ${ }^{11}$ Longer missions will experience some period of lunar night, depending on the location on the surface, and therefore require a significant amount of energy storage and the capability to recharge the energy storage during the lunar day. Staying throughout the lunar day/night cycle will also introduce greater temperature variation at the surface that will require significant additional thermal management capability. Longer missions may also be more adversely affected by dust, radiation, and micrometeorites, due to the additional time on the surface.

One approach that somewhat mitigates some of the challenges with longer duration stays is to establish the outpost at one of the lunar poles. The incident sunlight at the poles is at a lower angle than at the equator so the thermal profile is less variant, but colder. Also, elevated areas near the poles can have significantly greater durations of sunlight compared to equatorial sites due to the orientation and libration of the Moon. This can reduce the amount of energy storage needed as well as make photovoltaic arrays more effective at these sites. Conversely, some lower elevations near the poles (such as crater interiors) may see little or no sunlight, making these regions scientifically interesting as well. As a result, a site on the rim of Shackleton Crater near the lunar south pole has been used as a possible site for an outpost.

At the elevated polar sites, the solar illumination profile is governed more by the horizon terrain than by the orbital mechanics of the Sun-Earth-Moon system. The Sun is typically near the horizon at these sites and can be occulted by hills and other terrain a significant distance away. Detailed topographical maps and elevation models are lacking for the polar regions due the remote location and distance from past missions to the Moon. In the past decade there has been significant work in this area to interpret the available data and produce new elevation models. Summary of the past work has been documented in several papers by Fincannon. ${ }^{12-14}$ These papers also produced digital elevation models for the north and south polar regions as well as horizon profiles for specific sites near the poles. This paper focuses on one site identified as Site $4 \mathrm{RS}^{13}$ near the Shackleton Crater rim. Figure 1 shows an estimate of the horizon profile and Sun centerline position for January 2020 at Site 4RS. For this time period and location, the Sun is completely unocculted.

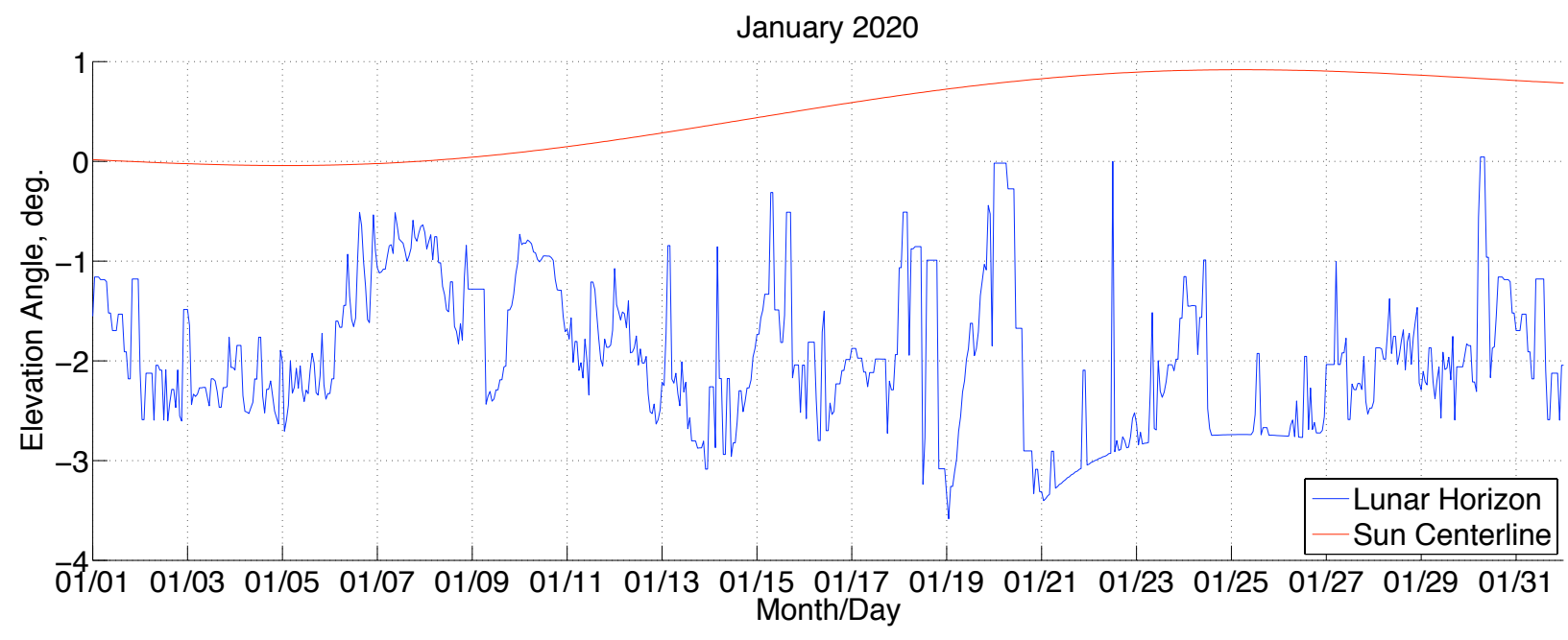

Figure 1. Estimated horizon terrain and Sun centerline for Site $4 \mathrm{RS},{ }^{13}$ near the Shackleton Crater rim and the lunar south pole, for January 2020. Data shown is from Fincannon. ${ }^{13}$

The time period shown encompasses an entire lunar rotation; the horizon can be seen to repeat itself near January 31, 2020. Figure 2 shows a different time period, September - October, 2020, and the corresponding interaction of the horizon and solar centerline profile. This timeframe shows the worst-case interaction, in which the minimum Sun location is near a significant set of hills on the horizon. The resulting period without sunlight can be seen to be multiple days; excluding the valley shown near October 1, 2020, the estimate is about 120 hours of continuous darkness at this site. Expanding the data shown in Figs. 1 and 2 for the period of years 2020 - 2030 and mapping the unocculted fraction of the Sun produces Fig. 3. This plot shows the 'summer' and 'winter' periods for this site, where the elevation angle of the Sun is higher than the 


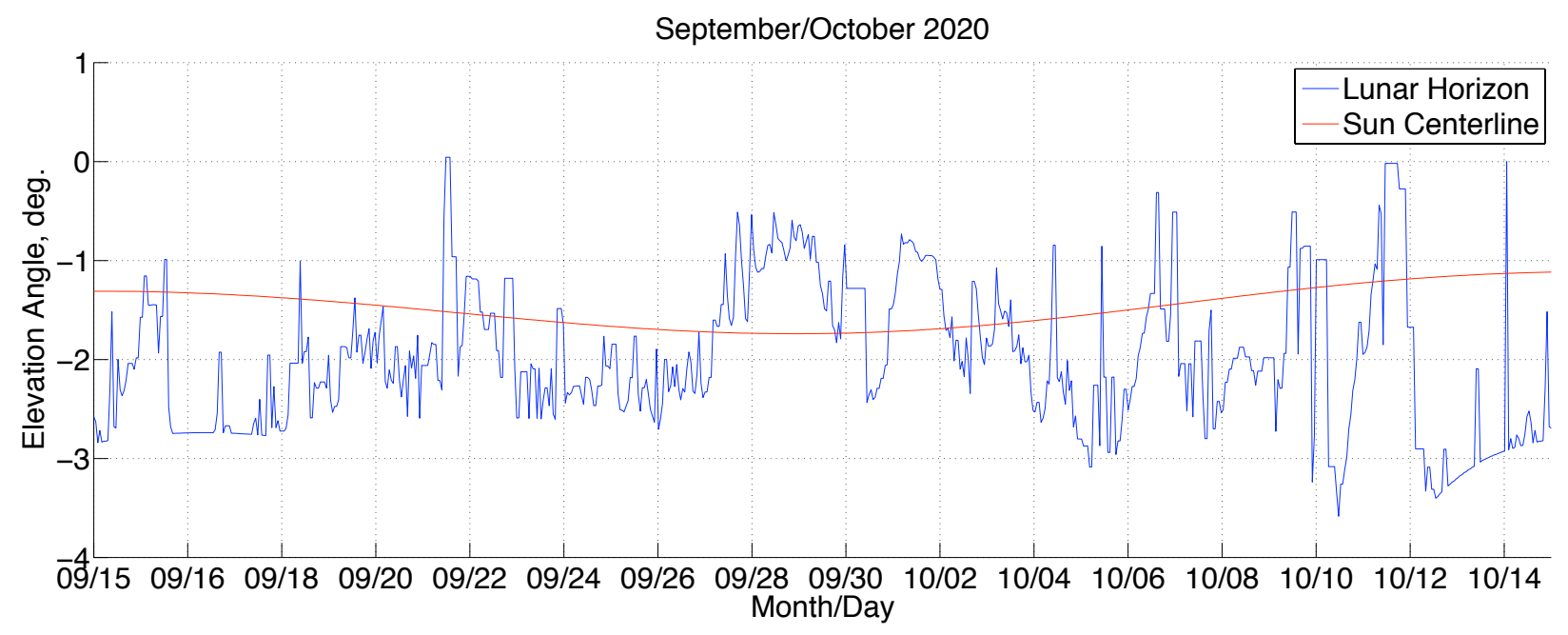

Figure 2. Estimated horizon terrain and Sun centerline for Site $4 R S,{ }^{13}$ near the Shackleton Crater rim and the lunar south pole, for September - October, 2020. Data shown is from Fincannon. ${ }^{13}$

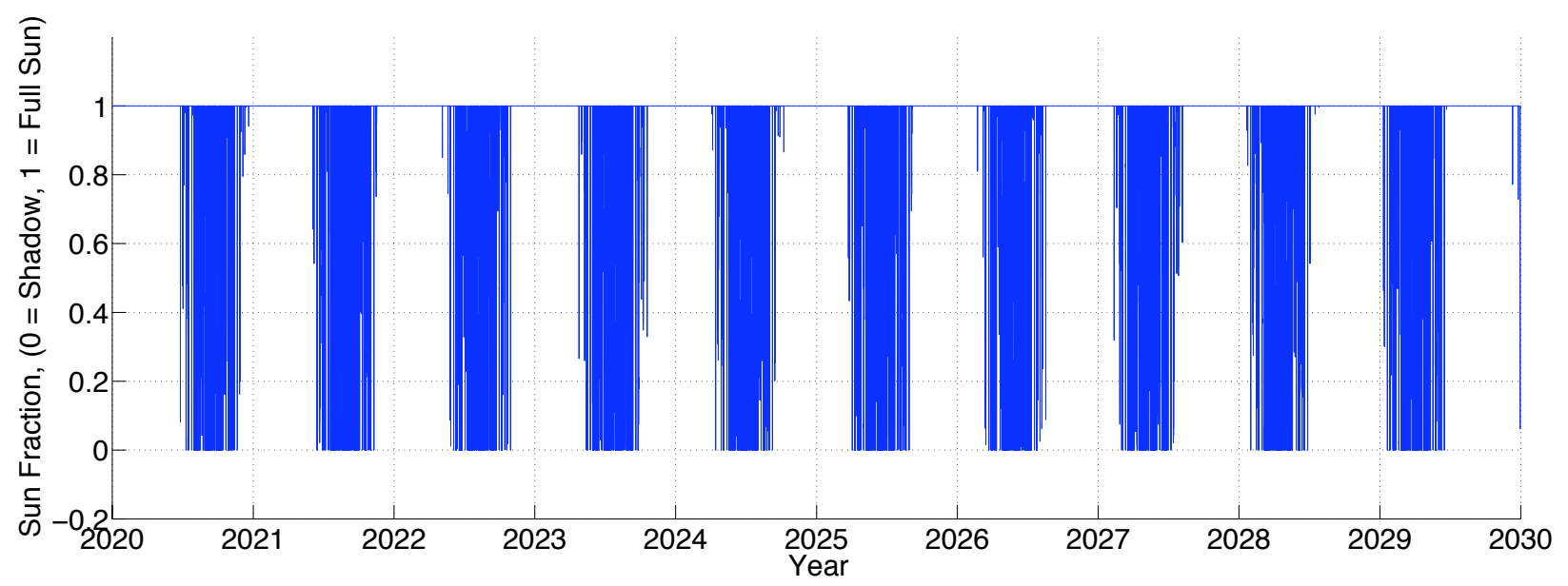

Figure 3. Estimated Sun illumination fraction for Site $4 \mathrm{RS},{ }^{13}$ near the Shackleton Crater rim and the lunar south pole, for the years 2020 - 2030. Data shown is from Fincannon. ${ }^{13}$ The Sun illumination fraction is defined as the fraction of the unocculted solar disk at the site specified. 


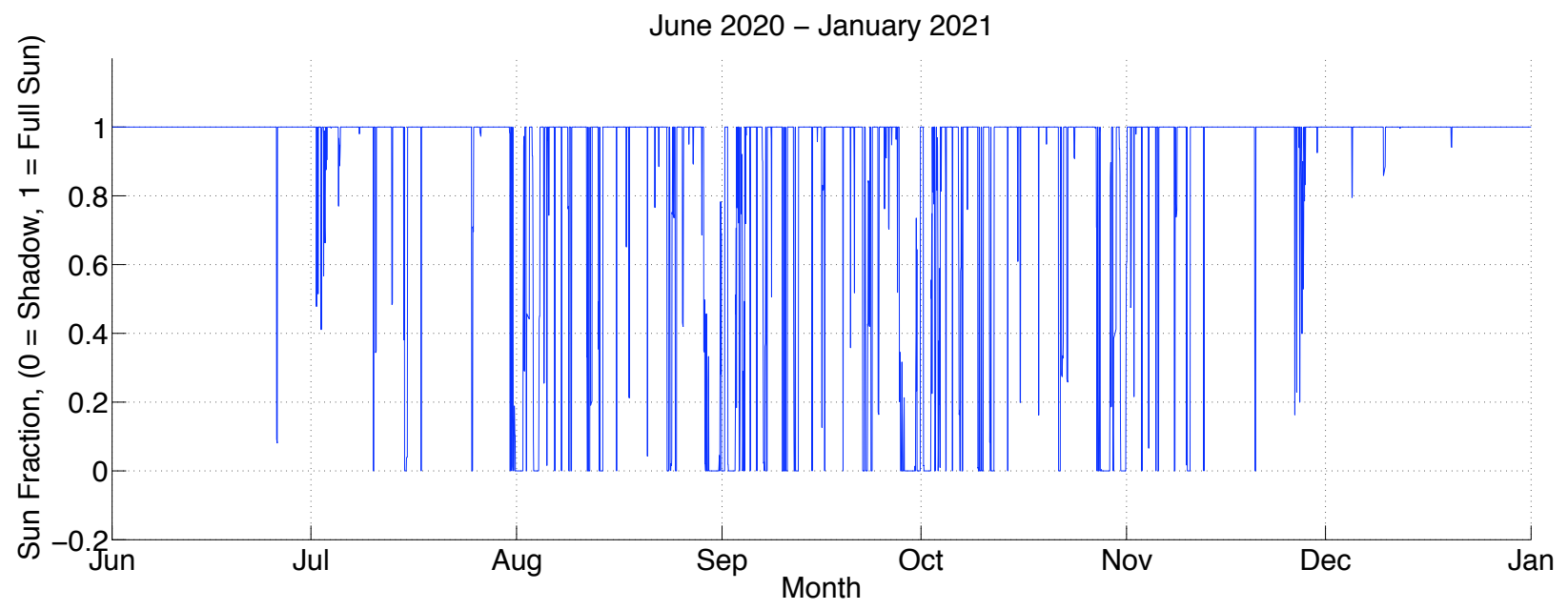

Figure 4. Estimated Sun illumination fraction for Site $4 R S,{ }^{13}$ near the Shackleton Crater rim and the lunar south pole, for June 2020 - January 2021. Data shown is from Fincannon. ${ }^{13}$ The Sun illumination fraction is defined as the fraction of the solar disk not occulted at the site specified.

terrain or intermittently lower than the terrain, respectively. The 'summer' periods are nearly six months of uninterrupted sunlight while the 'winter' periods are also approximately six months in duration but the change is gradual, as shown in Fig. 4, where the early and late portions of the time shown still contain significant lengths of time in illumination. It should be noted that the total cycle of illumination is less than an Earth year and can be seen in Fig. 3, where the 'winter' periods gradually become earlier each Earth year over the twelve years shown.

\section{Mathematical Models}

\section{A. Solar Array Subsystem}

The solar array subsystem model is an attempt to account for some of the major inefficiencies between an ideal photovoltaic cell and an actual solar array on the lunar surface for an extended period of time. The photovoltaic cell data is based on a published datasheet for the Emcore ${ }^{\mathrm{TM}}$ BTJ cell. ${ }^{15}$ This cell area is $26.6 \mathrm{~cm}^{2}$ with a specified efficiency of $28.5 \%$. While this cell could be considered current technology, it can be assumed that a better cell may be available by the time it is needed for this application. The sensitivity to this improvement will be examined in Section IV.D of this paper.

The solar array operating temperature is assumed to be $95^{\circ} \mathrm{C}$. One relevant analog is from the solar array on Surveyor VI, which recorded a maximum solar array temperature of $110^{\circ} \mathrm{C}^{16}$ This spacecraft was located at $41^{\circ} \mathrm{S}$, a warmer location, so the assumed value here could be expected to be lower than the $110^{\circ} \mathrm{C}$ measurement. The sensitivity to this value will also be evaluated in section IV.D.

The effect of temperature on cell performance is based on measured voltage and current values at a reference temperature, temperature coefficients from the Emcore ${ }^{\mathrm{TM}}$ datasheet, and the following equations from Rauschenbach. ${ }^{1}$ From the Emcore ${ }^{\mathrm{TM}}$ datasheet, $T_{\text {ref }}=28^{\circ} \mathrm{C}$.

$$
\begin{gathered}
V_{o c, T_{o p}}=V_{o c, T_{r e f}}+\frac{V_{o c}}{\Delta T}\left(T_{o p}-T_{r e f}\right) \\
V_{m p, T_{o p}}=V_{m p, T_{r e f}}+\frac{V_{m p}}{\Delta T}\left(T_{o p}-T_{r e f}\right) \\
I_{s c, T_{o p}}=A_{c e l l}\left(J_{s c}+\frac{J_{s c}}{\Delta T}\left(T_{o p}-T_{r e f}\right)\right) \\
I_{m p, T_{o p}}=A_{c e l l}\left(J_{m p}+\frac{J_{m p}}{\Delta T}\left(T_{o p}-T_{r e f}\right)\right)
\end{gathered}
$$


For the photovoltaic cell I-V curve, the third model described in Rauschenbach ${ }^{1}$ is used.

$$
\begin{gathered}
C_{1}=1-\frac{I_{m p}}{I_{s c}} e^{-\frac{V m p}{C_{2} V_{o c}}} \\
C_{2}=\frac{\left(\frac{V_{m p}}{V_{o c}}-1\right)}{\log \left(1-\frac{I_{m p}}{I_{s c}}\right)}
\end{gathered}
$$

With a given $V_{\text {cell }}$ value, $I_{\text {cell }}$ is found from

$$
I_{c e l l}=I_{s c, T_{o p}}\left(1-C_{1}\left(e^{\frac{V_{c e l l}}{C_{2} V_{o c}}}-1\right)\right)
$$

For this study, however, the solar array is assumed to operate at $\mathrm{V}_{m p}$. Also, the solar array is assumed to only operate when in full Sun (Sun illumination fraction $=1$ ). While the solar array will continue to produce power when illuminated by the partial solar disk, to be conservative, this effect was ignored.

Several additional losses are included. To account for dust accumulation on the solar array, a $1 \%$ loss per year is subtracted from $I_{m p}$ and $I_{s c}$. To account for losses due to radiation from both solar particle events and cosmic background radiation, a $1.2 \%$ loss per year is included for both the current terms and $V_{o c}$ and $V_{m p}$ as well. The effect of these assumptions will be included in the sensitivity analysis. Other loss assumptions include the cell mismatch loss, array flatness loss, coverglass/interconnect/cell (CIC) loss, misalignment loss, and a voltage drop due to the blocking diode. The cell mismatch loss accounts for differences in performance between individual cells and is assumed to be a $0.5 \%$ loss from $I_{m p}$ and $I_{s c}$. The array flatness loss accounts for differences in the angles of the individual cells and is assumed to be a cosine loss of $4^{\circ}$ from $I_{m p}$ and $I_{s c}$. The CIC loss accounts for losses due to integration of the cell with the interconnect and coverglass and its spectral properties and is assumed to be $1 \%$ of $I_{m p}$ and $I_{s c}$. The array is also assumed to have a $5^{\circ} \operatorname{cosine}$ loss from $I_{m p}$ and $I_{s c}$ due to misalignment with the Sun. Finally, the blocking diode imparts a voltage drop of $2 \%$ from $V_{o c}$ and $V_{m p}$.

The number of cells in series determines the solar array voltage and the number of cells in parallel determines the solar array current. There is a small resistance for each interconnect from the cell to the string, assumed to be $0.01 \Omega$. There is an additional resistance from each string to the array bus, assumed here to be $0.05 \Omega$. The solar array drive assembly (SADA) also has resistive losses that are assumed to be a bulk $0.02 \Omega$. The total number of cells is the product of the numbers in series and parallel and the array area is the product of the cell area and total number of cells, plus a packing factor that accounts for array area lost due to interconnects and packing inefficiencies of the shape of the cell. For the current work, a circular array is assumed that most likely does not fit cells together as well as a rectangular array, and therefore a packing factor of 0.85 is used. $^{1}$

In equation form,

$$
\begin{gathered}
I_{\text {string }}=I_{\text {cell }} \\
I_{\text {array }}=I_{\text {cell }} N_{\text {cells,parallel }} \\
R_{\text {string }}=R_{\text {interconnect }} N_{\text {cells,string }}+R_{\text {string-to-array }} \\
V_{\text {string }}=V_{\text {cell }} N_{\text {cells,string }}-I_{\text {string }} R_{\text {string }} \\
V_{\text {array }}=V_{\text {string }}-I_{\text {array }} R_{S A D A} \\
N_{\text {cells }, \text { total }}=N_{\text {cells,string }} N_{\text {cells }, \text { parallel }} \\
A_{\text {array }}=\frac{A_{\text {cell }} N_{\text {cells,total }}}{f_{\text {packing }}} \\
r_{\text {array }}=\sqrt{\frac{A_{\text {array }}}{\pi}}
\end{gathered}
$$

Each solar array wing subsystem mass is assumed to be made up of the solar array wing itself, a SADA, and some secondary support structure. For this analysis, each SADA is assumed to be $10 \mathrm{~kg}$, and the secondary structure is assumed to be $10 \mathrm{~kg}$ as well. The wing mass is assumed to be a simple function of its area by using a specific mass of $2 \mathrm{~kg} / \mathrm{m}^{2}$. The maximum circular array radius is assumed to be $4.5 \mathrm{~m}$. For requirements above this value, two smaller arrays are used. The total mass of the solar array subsystem is,

$$
m_{\text {array }}=\bar{m}_{\text {array }} A_{\text {array }}+N_{\text {arrays }} m_{S A D A}+N_{\text {arrays }} m_{\text {structure }}
$$




\section{B. Battery Subsystem}

The battery subsystem model is based on an assumed charge and discharge efficiency value. For this analysis, charge and discharge efficiencies of 0.97 and 0.98 are used respectively. A degradation of $1 \%$ per year in these values is included.

$$
\begin{gathered}
P_{(\text {to battery })}=\eta_{\text {charge }} P_{(\text {from array })} \\
P_{(\text {to load })}=\eta_{\text {discharge }} P_{(\text {from battery })}
\end{gathered}
$$

The total battery energy is based on a maximum allowable depth-of-discharge, assumed here to be $90 \%$. While this value is high, for this application, the system will rarely be discharged that much. For the battery subsystem mass, a specific energy of $150 \mathrm{Whr} / \mathrm{kg}$ at the battery system level is assumed. Sensitivities to the specific energy will be included to account for the uncertainty in this value.

\section{Regenerative Fuel Cell Subsystem}

The regenerative fuel cell (RFC) subsystem is assumed to include polymer electrolyte membrane (PEM) fuel cell and electrolyzer stacks, high pressure gaseous hydrogen and oxygen tanks, and the required plumbing, controls, and other components necessary for a working fluid system.

The fuel cell and electrolyzer performance are based on the equations derived in Larminie and Dicks. ${ }^{17}$ The baseline cell voltages $\left(V_{\text {cell }}\right)$ are assumed to be $0.85 \mathrm{~V}$ for the fuel cell and $1.6 \mathrm{~V}$ for the electrolyzer. These values are degraded by $1 \%$ year (fuel cell voltage decreased and electrolyzer cell voltage increased) in a similar way to the battery degradation. These values will be examined in the sensitivity analysis. The molar flow rates are as follows,

$$
\begin{gathered}
\dot{m}_{H_{2}}=\frac{P}{2 V_{\text {cell }} F} \\
\dot{m}_{O_{2}}=\frac{\dot{m}_{H_{2}}}{2} \\
\dot{m}_{H_{2} O}=\dot{m}_{H_{2}} .
\end{gathered}
$$

The heat produced by the fuel cell is estimated based on the lower heating value of hydrogen. The electrolyzer will most likely also require cooling but is expected to be less than or similar to that of the fuel cell, so $Q_{f c}$ is used to size the thermal subsystem.

$$
Q_{f c}=P\left(\frac{1.25}{V_{\text {cell }}}-1\right)
$$

The RFC subsystem requires some additional power load to account for fluid pumping and thermal management throughout the system. For this study a constant value of $100 \mathrm{~W}$ is used during both charge and discharge of the subsystem.

The fuel cell and electrolyzer stack masses can be simplified to be functions of the nominal power requirements. For this analysis, a constant value of $35 \mathrm{~kg}$ is used for each fuel cell stack because the net fuel cell power requirement is also constant at $2 \mathrm{~kW}$. Each electrolyzer stack is assumed to be $50 \mathrm{~kg}$ because the charge power can be significantly higher depending on the solar array size. A few options in the following analysis have significantly larger solar array area and for these options, the electrolyzer mass is doubled. The ancillary components may include gaseous or liquid pumps, gas driers, the fluid lines, valves, and other components. For this study, a rough estimate of $30 \mathrm{~kg}$ is used for each fuel cell and electrolyzer stack ancillary system.

The hydrogen and oxygen tanks are based on composite overwrapped pressure vessel technology. The pressure of the tanks is assumed to be driven by the electrolyzer stacks and the maximum pressure most likely will be between 13.8 and $20.7 \mathrm{MPa}$ (2000 and $3000 \mathrm{psi}$ ). The tanks are sized to hold the necessary hydrogen and oxygen including the amount needed to prevent greater than $90 \%$ 'depth-of-discharge,' as in the battery case. For this study, the dry mass of the hydrogen tank is calculated from an assumed constant $10 \%$ hydrogen mass fraction. Similarly, the dry mass of the oxygen tank is calculated from an assumed constant $50 \%$ oxygen mass fraction. The equation used is

$$
m_{\text {tank }, \text { dry }}=\frac{m_{\text {fluid }}}{m f_{\text {fluid }}}-m_{\text {fluid }} .
$$


While this does not account for the potential mass fraction improvement in larger tanks, it is sufficient for this study. An additional $10 \mathrm{~kg}$ is added to each tank, regardless of the amount of fluid, for non-scaling components such as the fluid interface and structural components.

The approach to RFC mass is coarse but the intent is to capture general magnitudes and the effect of the changing amounts of hydrogen and oxygen depending on the overall system design. This is a primary difference compared to a battery: only the fluids scale with energy for the RFC, where the entire battery system scales with energy. As the energy storage requirements increase, the metric of overall mass per energy should trend toward the RFC system because of this difference in scaling. ${ }^{18}$

\section{Power Management and Distribution Subsystem}

A top-level power management and distribution subsystem is included to account for the mass and losses from the major components of the subsystem. This study assumes an energy storage bus voltage of $28 \mathrm{Vdc}$. The solar array, because of its likely higher power production requirement, is assumed to have an output voltage $\left(V_{\text {array }}\right)$ of $120 \mathrm{Vdc}$. Therefore, a DC-DC converter is needed to step the voltage down to the 28 Vdc level. This converter is assumed to have a $90 \%$ efficiency. A second power management component is a central switching unit that handles the channel routing and fault tolerance and protection for each subsystem. This unit is also assumed to have an efficiency of $90 \%$ both for charging and discharging. Both the converter and switching unit are estimated at $20 \mathrm{~kg}$ each, irrespective of power levels. The other major components are the cables and their connectors. A placeholder of $20 \mathrm{~kg}$ is used for power system internal cables and connectors. Voltage drops from the cables and connectors that are local to the power system are accounted for through the efficiencies and resistances described above. Cables and related losses external to the power system are not included. Finally, similar to the electrolyzer mass estimates, when significantly larger solar arrays are used in the following analysis, the PMAD mass is doubled. Top-level schematics of the lunar daytime and nighttime PMAD diagrams are shown in Figs. 5 and 6.

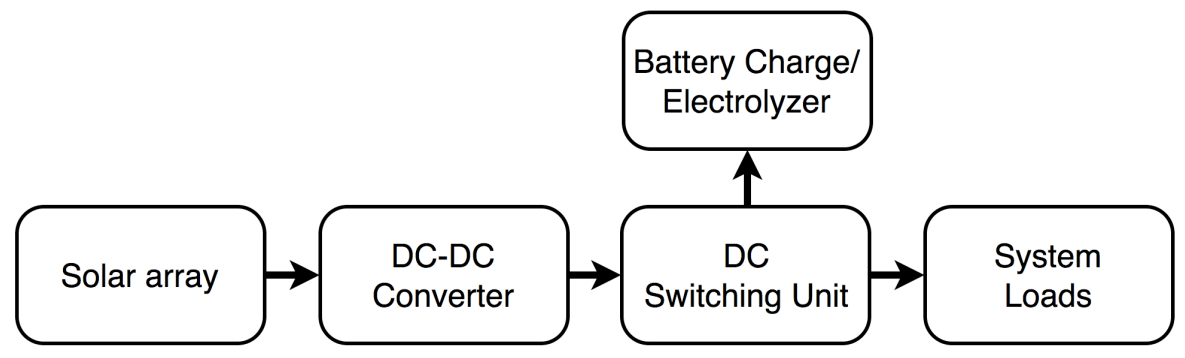

Figure 5. Power system schematic for lunar daytime operation.

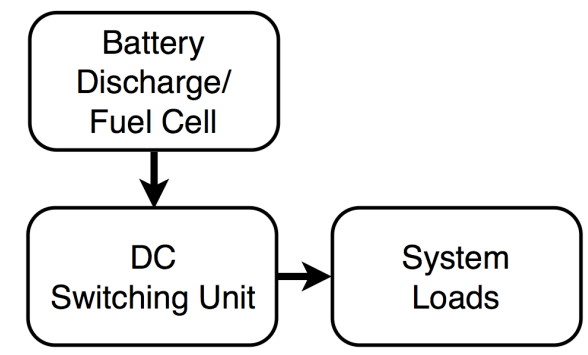

Figure 6. Power system schematic for lunar nighttime operation.

\section{E. Thermal Subsystem}

A top-level radiator model is included to account for greater cooling needs of the RFC subsystem compared to the battery subsystem. The battery subsystem most likely requires some thermal management, but the RFC most likely requires a more significant thermal system including an active cooling loop. The approximate 
area is calculated from the radiation equation with an assumed effectiveness of 0.9 , an assumed emissivity of 0.9 , an assumed radiator fluid temperature of $320 \mathrm{~K}$ and an assumed sink temperature of $250 \mathrm{~K}$. The radiator fluid temperature is based on a PEM fuel cell operating temperature of between $330 \mathrm{~K}$ and $350 \mathrm{~K}$. To convert the radiator area into an estimate of radiator mass, a specific mass of $5 \mathrm{~kg} / \mathrm{m}^{2}$ is assumed.

$$
\begin{gathered}
A_{\text {rad }}=\frac{Q_{f c}}{\eta_{\text {rad }} \epsilon_{\text {rad }} \sigma\left(T_{\text {rad }}^{4}-T_{\text {sink }}^{4}\right)} \\
m_{\text {rad }}=\bar{m}_{\text {rad }} A_{\text {rad }}
\end{gathered}
$$

\section{F. Redundancy and Fault Tolerance}

Decisions on subsystem redundancy or fault tolerance can be mission- and scenario-dependent but can have significant effects on the overall system mass. Fault tolerance for solar arrays can be handled by using multiple wings to provide some capability to recover from a SADA or deployment failure. Once the array is deployed, it rarely entirely fails. Batteries, like solar arrays, consist of connected cells in series and parallel configurations, so that if there is a failure, it may only disable a single string or subset of the entire subsystem. Batteries are therefore not typically fully redundant but possibly oversized to handle a string fault.

A regenerative fuel cell subsystem may require a different approach to handle redundancy. The Space Shuttle fuel cells are dual-fault tolerant, in which three completely independent stack assemblies are each capable of meeting the nominal loads. ${ }^{19}$ This approach is used here for the RFC system and its ancillary components. For an outpost with multiple modules, the redundancy could most likely be reduced with modules delivered later. For the RFC tanks, two tanks each of hydrogen and oxygen are assumed.

\section{G. System Load Profile}

The load profile used here follows the Sun illumination profile shown in Fig. 3. When the site is illuminated, the power load is assumed to be $5 \mathrm{~kW}$. When in shadow, the power load is assumed to be $2 \mathrm{~kW}$. These loads are thought of as module-level power loads, with a larger outpost requiring multiple modules. Matching the power loads to the illumination profile can simulate an actual outpost that is more active during illuminated periods and allows only necessary power loads during shadowed periods. For the south pole site, this may be realistic due to the short periods in shadow and the long, active 'summer' period. During crew nighttime periods in the 'summer,' when the crew is sleeping, the additional power loads that makeup the $5 \mathrm{~kW}$ assumption may come from recharging of mobile vehicles or ongoing scientific studies, for example.

\section{Results and Discussion}

\section{A. Solar Array and Battery System}

The required battery energy is dependent on the capability of the solar array; a larger solar array provides more charge power, enabling the battery to charge quicker and therefore be better prepared for the next discharge period. For an essentially random charge/discharge distribution such as at this site, the effect of a larger solar array is more pronounced. This effect is shown in Fig. 7. The nonlinearity can be explained by comparing the state-of-charge profiles for Options 0 and 1, show in Figs. 8 and 9 . In the latter part of Fig. 8, the solar array is not able to recharge the battery subsystem before the next discharge period, thus beginning that period with a less than fully charged battery. Since the energy storage is sized based on a maximum $90 \%$ depth of discharge, this directly effects the overall battery subsystem size. The result can also be seen in the early years, where the much larger battery subsystem in Fig. 8 has a lower depth-of-discharge than that shown in Fig. 9. As a result, almost $80 \%$ of the larger battery subsystem is essentially not used for the first six years because of an undersized solar array. It should also be noted that though degradation of the battery and solar arrays are part of the reason for increased depth-of-discharge over the decade, the ability to recharge before the next discharge period is a more dominant effect.

The four Options for combined solar array/battery systems shown in Fig. 7 are presented in Table 1. For Option 0, the solar array size is relatively small, but the batteries are much too heavy. For Option 1, the

solar array size is chosen to be near the primary 'elbow' in Fig. 7. For this case, the batteries still dominate the overall system mass. Option 2 enlarges the solar array to the maximum diameter allowed (specified earlier as $9 \mathrm{~m}$ ). This slightly improves the overall system mass despite a heavier solar array subsystem. 


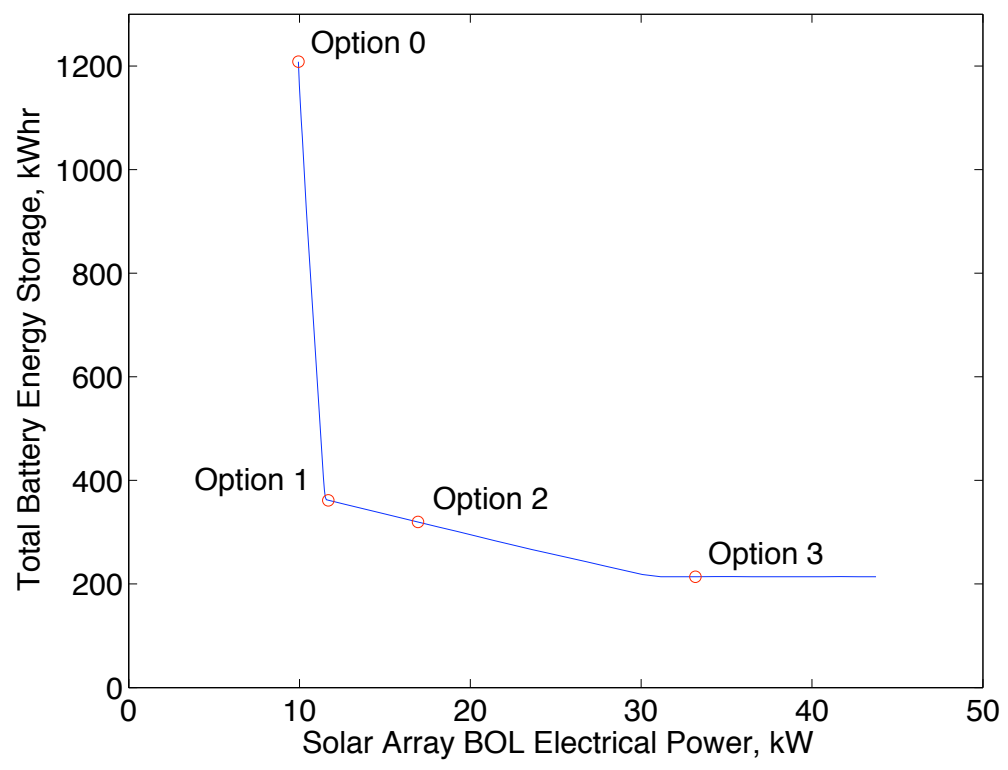

Figure 7. Plot of total battery energy storage required for a given solar array size.

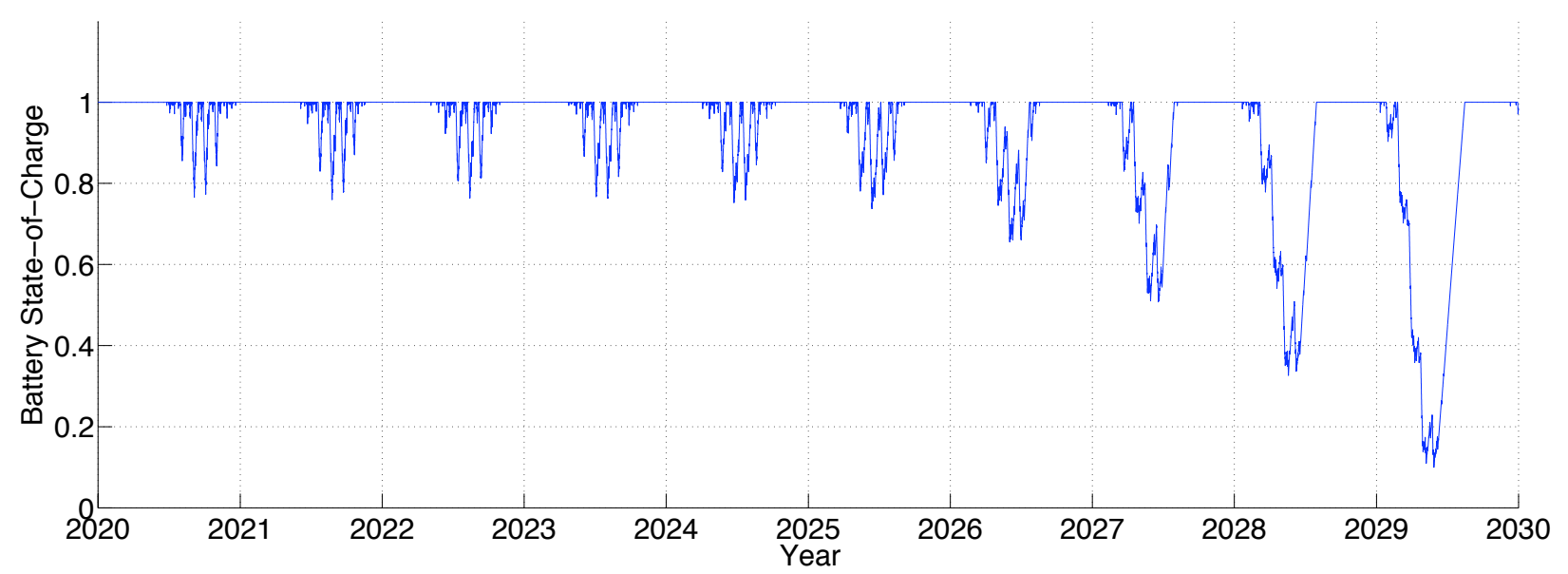

Figure 8. Plot of state-of-charge for the battery subsystem for the entire 2020 - 2030 period. The total battery energy is $1208 \mathrm{kWhr}$, the solar array area is $37.0 \mathrm{~m}^{2}$ and the BOL solar array power is $9.9 \mathrm{~kW}$. This system is Option 0 in Table 1. 


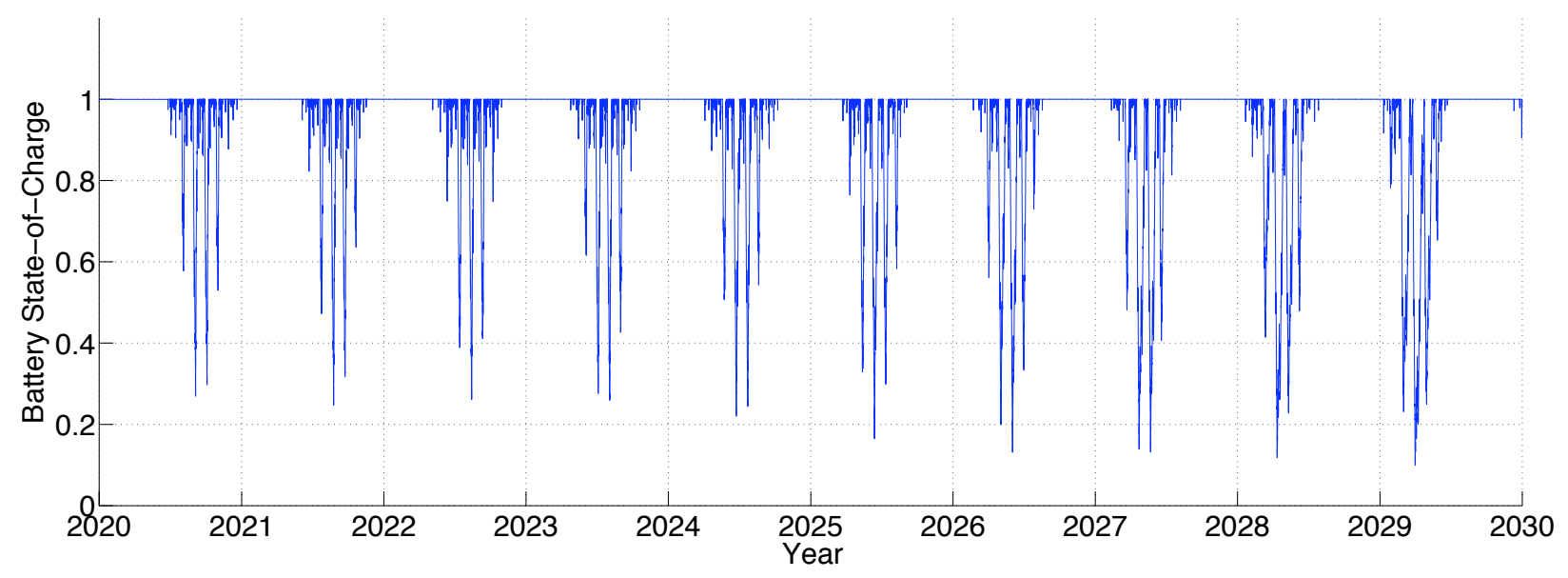

Figure 9. Plot of state-of-charge for the battery subsystem for the entire 2020 - 2030 period. The total battery energy is $362 \mathrm{kWhr}$, the solar array area is $43.6 \mathrm{~m}^{2}$ and the BOL solar array power is $11.7 \mathrm{~kW}$. This system is Option 1 in Table 1.

Adding another $9 \mathrm{~m}$ solar array is shown as Option 3. The battery subsystem is significantly reduced at the expense of two large solar arrays producing $33.9 \mathrm{~kW}$ of BOL power where only $5 \mathrm{~kW}$ is required for the daytime power load, which is probably unrealistic from an outpost perspective. Option 2 is chosen for further analysis. Figures 10 and 11 show the Option 2 state-of-charge detail for years 2020 and 2029. These plots show typical years and the changes over the decade for the battery subsystem. Figure 12 shows the estimated charge and discharge rates for the Option 2 battery subsystem.

Table 1. Options for a Combined Solar Array/Battery System.

\begin{tabular}{rcccc} 
Parameter & Option 0 & Option 1 & Option 2 & Option 3 \\
\hline Total Solar Array Area $\left(\mathrm{m}^{2}\right)$ & 37.0 & 43.6 & 63.6 & 127 \\
Solar Array Diameter $(\mathrm{m})$ & 6.9 & 7.5 & 9.0 & $2 \mathrm{x} 9.0$ \\
Total Solar Array BOL Power $(\mathrm{kW})$ & 9.9 & 11.7 & 16.9 & 33.9 \\
Total Battery Energy $(\mathrm{kWhr})$ & 1208 & 362 & 320 & 214 \\
& & & & \\
\hline Solar Array System Mass $(\mathrm{kg})$ & 94 & 107 & 147 & 294 \\
Battery System Mass $(\mathrm{kg})$ & 8055 & 2411 & 2131 & 1428 \\
PMAD System Mass $(\mathrm{kg})$ & 60 & 60 & 60 & 120 \\
\hline Total System Mass $(\mathrm{kg})$ & 8209 & 2578 & 2338 & 1842
\end{tabular}

The long periods of time spent fully charged may introduce a minor issue of the battery subsystem selfdischarging over these periods. To mitigate this issue, the solar arrays could be expected to trickle charge the batteries throughout this period, but this would not impact the overall system significantly.

\section{B. Solar Array and Regenerative Fuel Cell System}

The approach for the solar array/RFC combination is similar to that of the solar array/battery approach above. The system behaves in a similar manner, in which the solar array capability has a significant effect of the energy storage of the RFC. This effect is shown in Fig. 13. The units of energy storage for the RFC in this paper are moles of hydrogen. Plots similar to Figs. 8 and 9 are shown in Figs. 14 and 15. Comparing Fig. 14 to Fig. 8, the RFC case shows a greater amount of time with a less than full hydrogen tank. Also, the slope of the recharge portions of the RFC plot are lower, indicating a lower efficiency compared to the battery system. The lower efficiency of the RFC requires additional solar array power to maintain a full hydrogen tank. A larger solar array is used in Fig. 15 and the result is a much better 'state-of-charge' profile. 
Year 2020

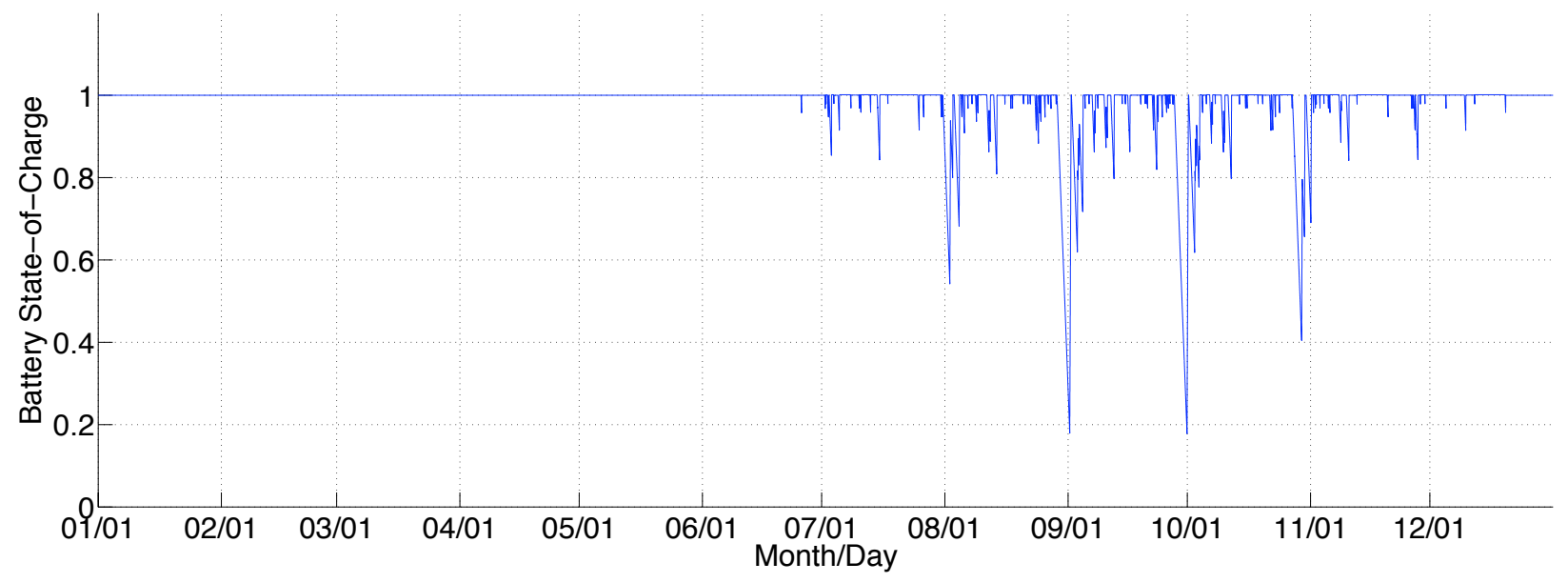

Figure 10. Plot of state-of-charge for Option 2 of Table 1 for the year 2020.

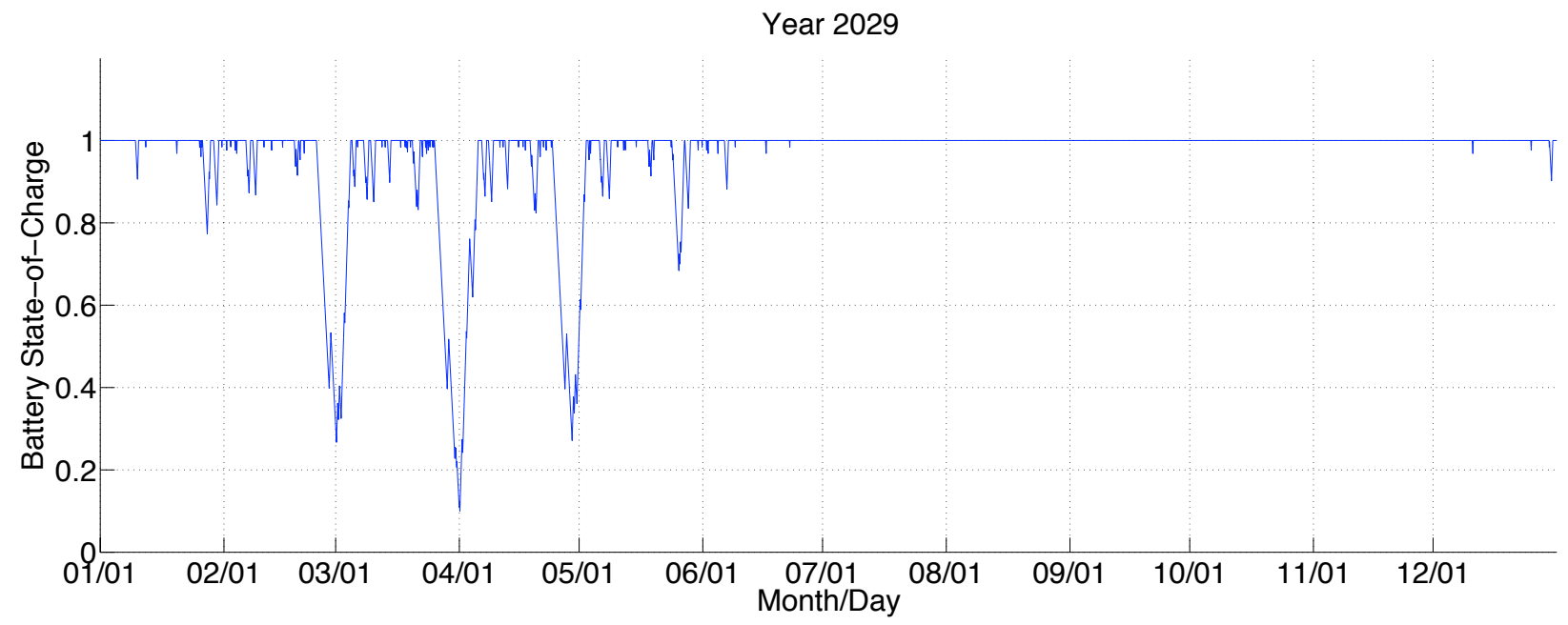

Figure 11. Plot of state-of-charge for Option 2 of Table 1 for the year 2029.

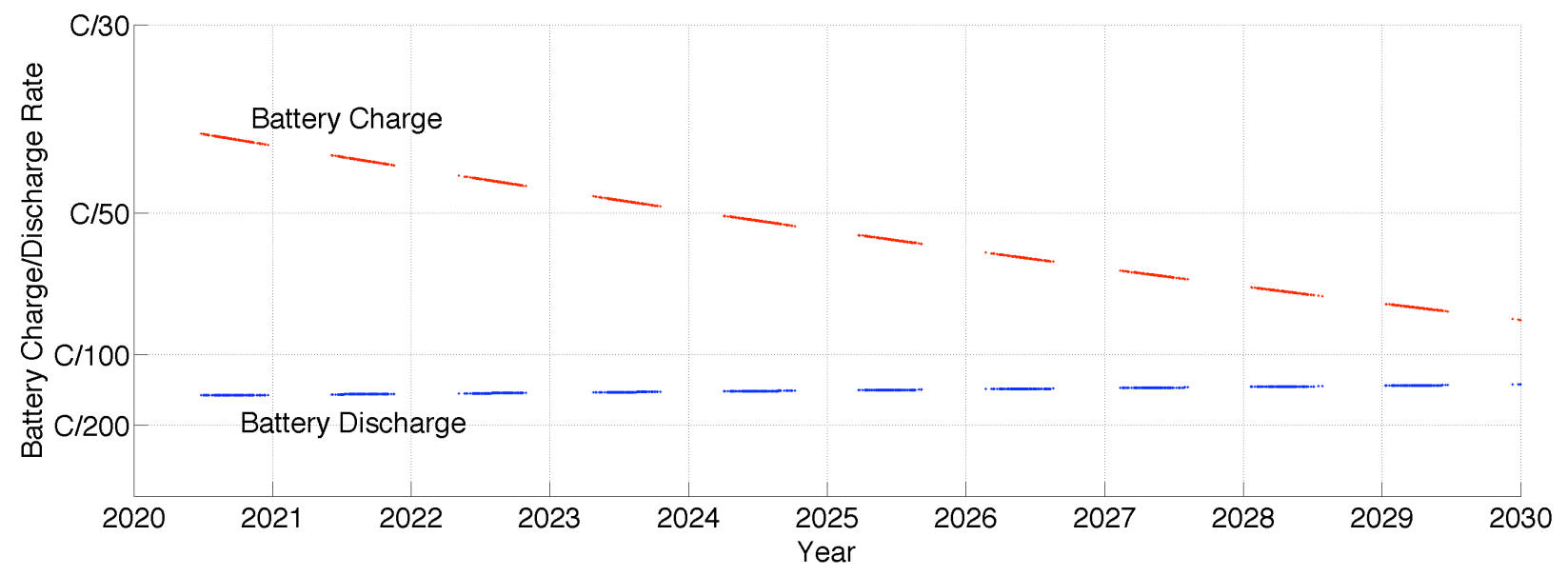

Figure 12. Plot of estimated charge and discharge rates for Option 2 of Table 1. 


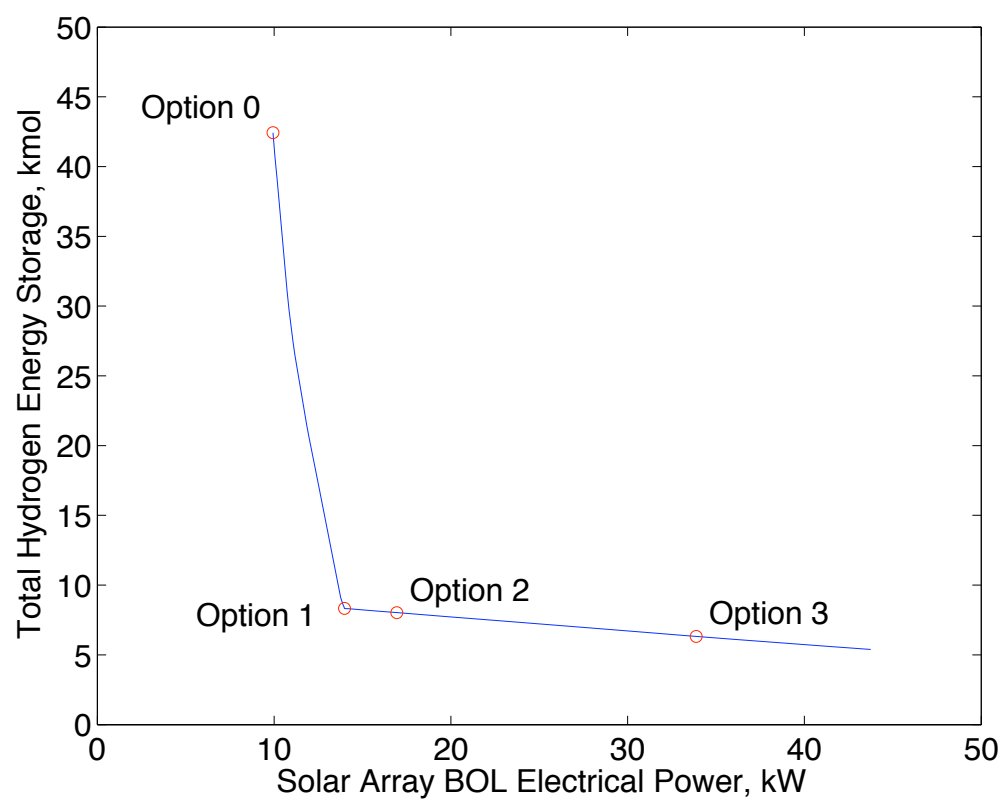

Figure 13. Plot of total hydrogen energy storage within an RFC system required for a given solar array size.

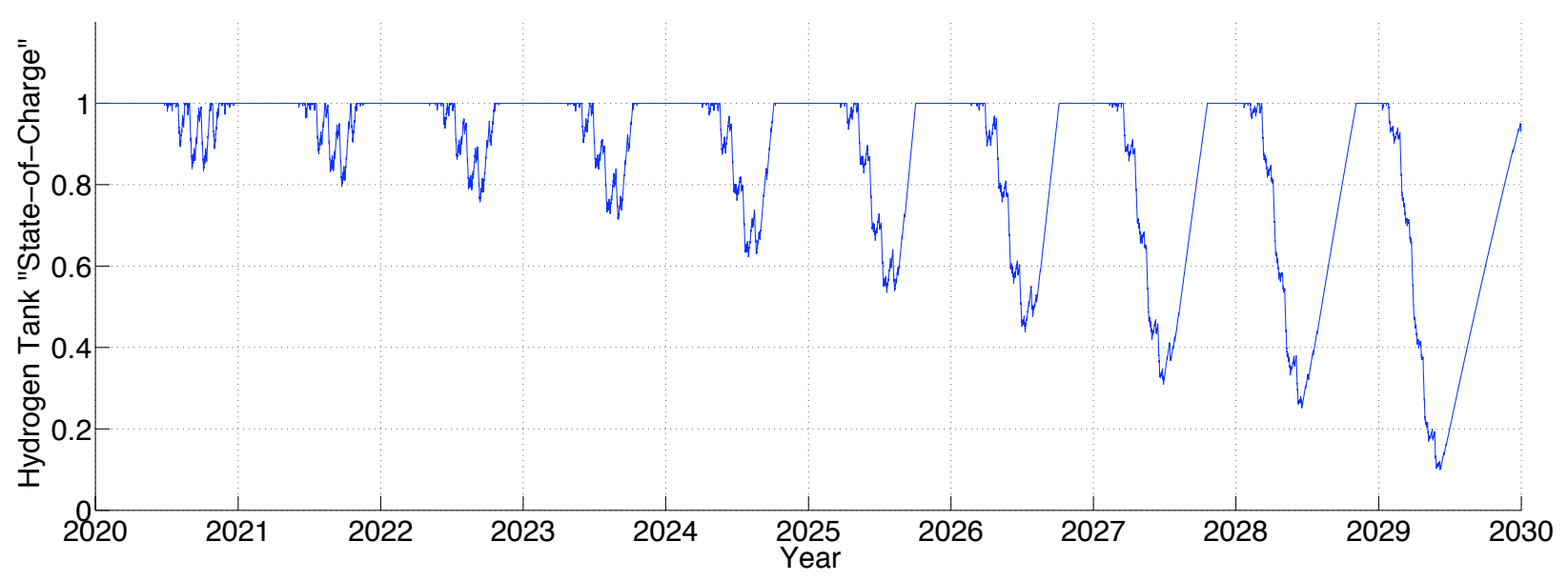

Figure 14. Plot of hydrogen tank 'state-of-charge' for the RFC subsystem for the entire 2020 - 2030 period. The total amount of hydrogen is $85.7 \mathrm{~kg}$, the solar array area is $37.0 \mathrm{~m}^{2}$ and the BOL solar array power is $9.9 \mathrm{~kW}$. This system is Option 0 in Table 2. 


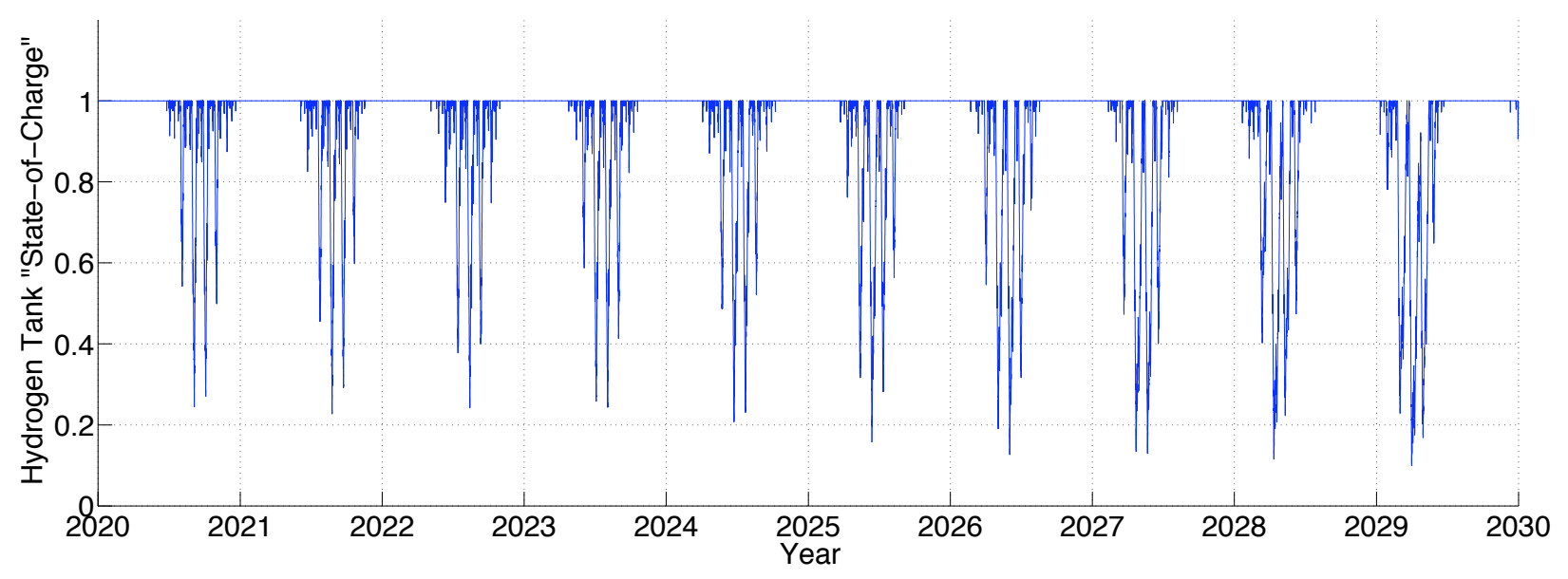

Figure 15. Plot of hydrogen tank 'state-of-charge' for the RFC subsystem for the entire 2020 - 2030 period. The total amount of hydrogen is $16.8 \mathrm{~kg}$, the solar array area is $52.3 \mathrm{~m}^{2}$ and the BOL solar array power is $14.0 \mathrm{~kW}$. This system is Option 1 in Table 2.

This solar array size is chosen to be near the 'elbow' in Fig. 13 similar to the Option 1 battery case. Option 2 increases the single solar array size to the specified $9 \mathrm{~m}$ diameter maximum. The Option $3 \mathrm{RFC}$ system is similar to Option 3 for the battery case, in which two $9 \mathrm{~m}$ diameter solar arrays are used in combination with the RFC. For the RFC, however, the larger solar arrays are actually detrimental to the overall system mass: though the fluids and their tanks decrease in mass, the solar arrays, PMAD, and electrolyzer subsystem get heavier due to the higher power levels. These Options are shown in Table 2.

Table 2. Options for a Combined Solar Array/RFC System.

\begin{tabular}{rcccc} 
Parameter & Option $\mathbf{0}$ & Option $\mathbf{1}$ & Option 2 & Option 3 \\
\hline Total Solar Array Area $\left(\mathrm{m}^{2}\right)$ & 37.0 & 52.3 & 63.6 & 127 \\
Solar Array Diameter $(\mathrm{m})$ & 6.9 & 8.2 & 9.0 & $2 \mathrm{x} 9.0$ \\
Total Solar Array BOL Power $(\mathrm{kW})$ & 9.9 & 14.0 & 16.9 & 33.9 \\
& & & & \\
\hline Solar Array System Mass $(\mathrm{kg})$ & 94 & 125 & 147 & 294 \\
Total Hydrogen Mass $(\mathrm{kg})$ & 85.7 & 16.8 & 16.2 & 12.8 \\
Total Oxygen Mass $(\mathrm{kg})$ & 679 & 133 & 128 & 101 \\
Total Hydrogen Tank Mass $(\mathrm{kg})$ & 791 & 171 & 166 & 135 \\
Total Oxygen Tank Mass $(\mathrm{kg})$ & 699 & 153 & 148 & 121 \\
Total Fuel Cell Subsystem Mass $(\mathrm{kg})$ & 195 & 195 & 195 & 195 \\
Total Electrolyzer Subsystem Mass $(\mathrm{kg})$ & 240 & 240 & 240 & 480 \\
Thermal System Mass $(\mathrm{kg})$ & 16 & 16 & 16 & 16 \\
PMAD System Mass $(\mathrm{kg})$ & 60 & 60 & 60 & 120 \\
\hline Total System Mass $(\mathrm{kg})$ & 2860 & 1110 & 1116 & 1475
\end{tabular}

Figures 16 and 17 show the Option 2 hydrogen tank 'state-of-charge' detail for years 2020 and 2029 . Option 2 for the RFC system is chosen for comparison with the Option 2 battery system, though the RFC Option 1 may be a better choice due to its lower mass and smaller solar array. Figure 18 shows the estimated charge and discharge rates in terms of hydrogen flow rate for the Option 2 RFC subsystem. 
Year 2020

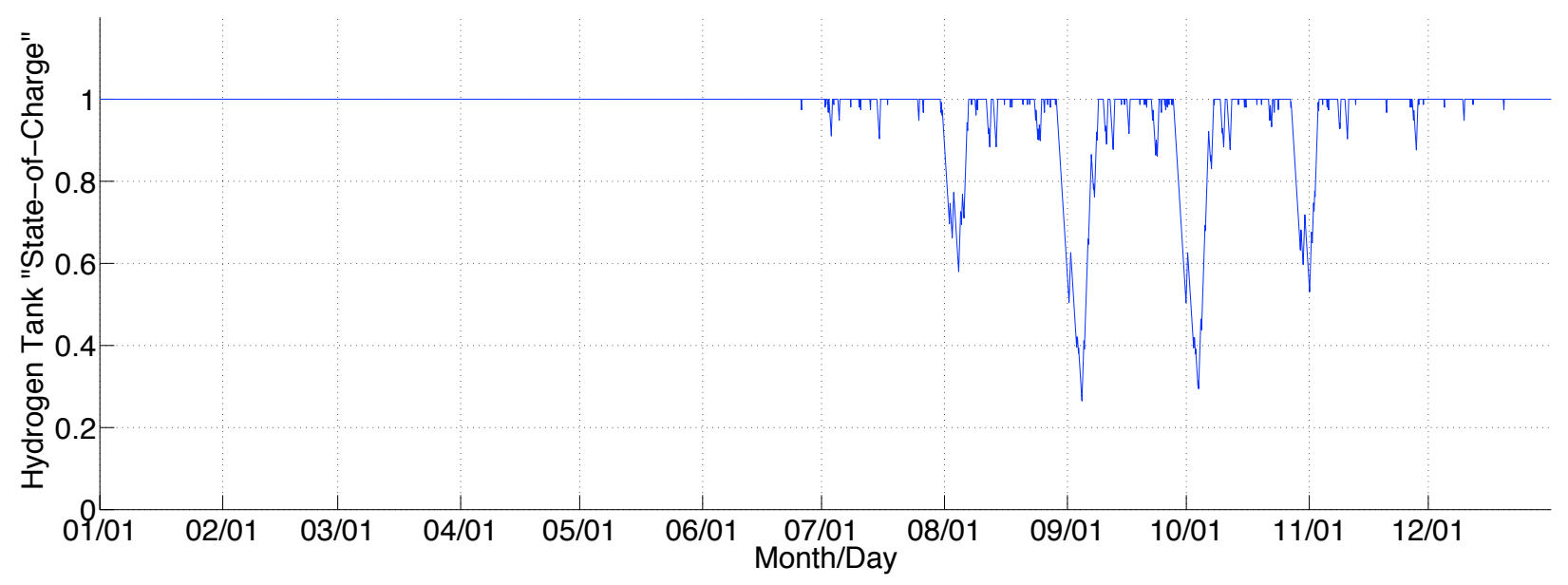

Figure 16. Plot of hydrogen tank 'state-of-charge' for Option 2 of Table 2 for the year 2020.

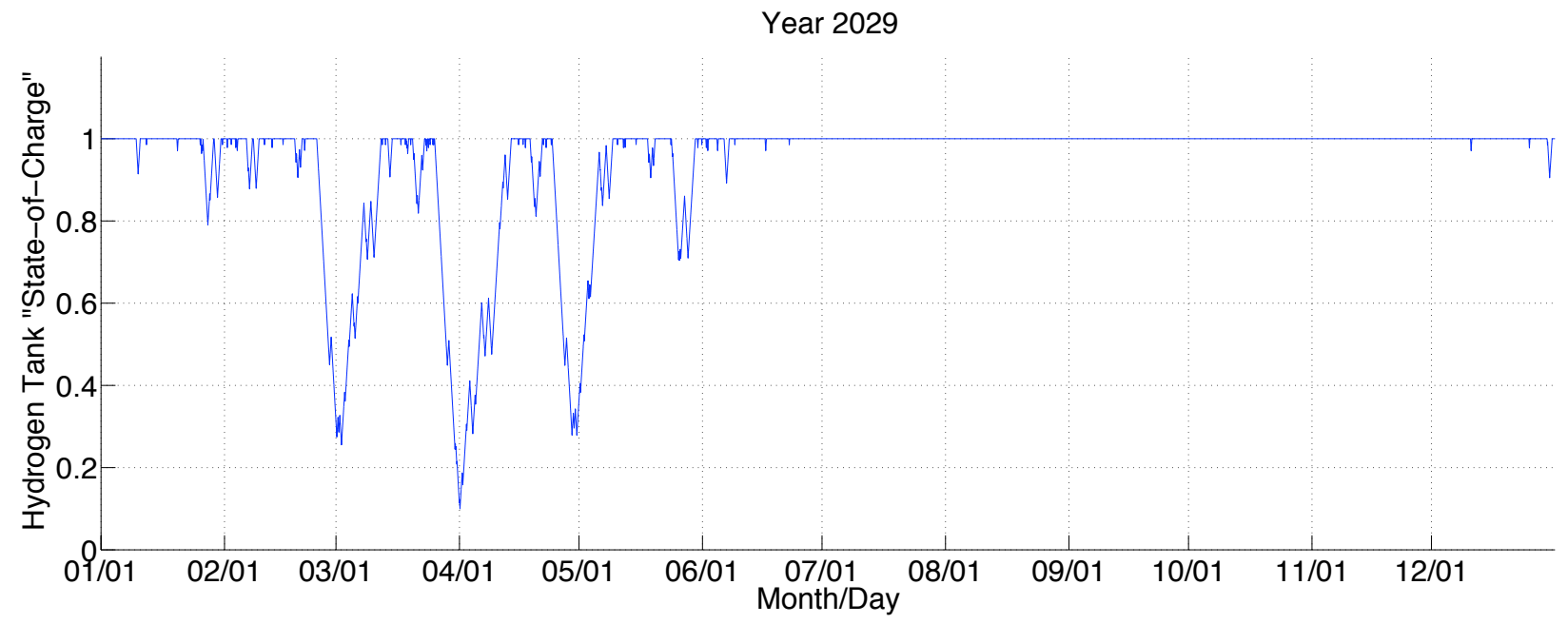

Figure 17. Plot of hydrogen tank 'state-of-charge' for Option 2 of Table 2 for the year 2029.

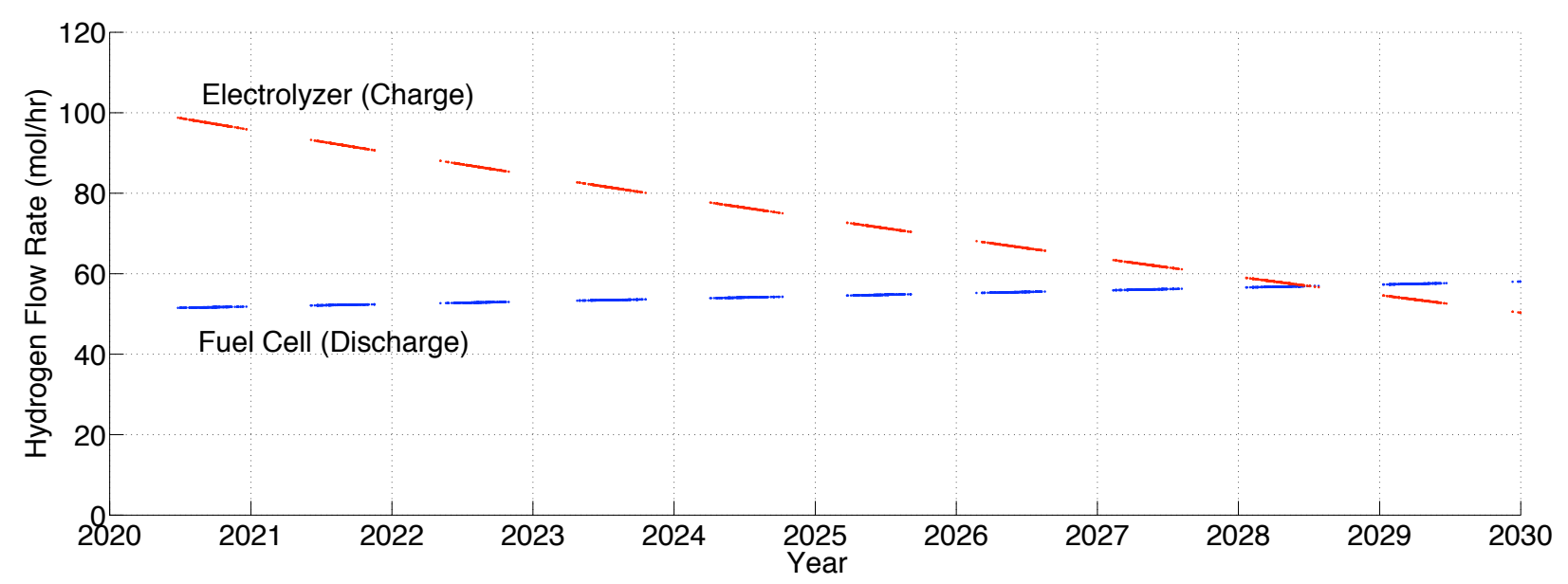

Figure 18. Plot of estimated charge and discharge rates in terms of hydrogen flow rate for Option 2 of Table 2. 


\section{Cycle, Calendar, and Operating Life}

Based on the assumption that such a power module would be required to operate over the entire 2020 - 2030 timeframe, one can estimate the number of charge/discharge cycles, operating time, and other requirements using the above results. Looking at Figs. 10 and 11, there are only a few deep discharges of the battery each year. For the entire decade, there may nominally be only 40 - 50 significant discharges for the system. There are about 20 discharges in the $10 \%-20 \%$ SOC range each year as well. The system is sized for the deep discharges, but the majority of the time is spent fully charged or at least greater than $80 \%$ state-of-charge. This has good implications for the potential life and reliability of the battery subsystem as well as potentially greater performance that may be possible from a particular cell.

Figures 16 and 17 show that the number and magnitude of charge/discharge cycles for the RFC case to be similar to that of the battery case. This is also good for life and reliability of the RFC subsystem since the cycling of pressure and temperature can be problematic for composite tanks, PEM stacks, and other components. The thermal cycling is also a reason why higher temperature fuel cells and electrolyzers may not be ideal for this application.

The modeled operation of the battery, fuel cell, and electrolyzer subsystems in their Option 2 designs is used to estimate operating life. These values are shown in Table 3. For both the battery discharge and fuel

Table 3. Estimated minimum annual operating time for discharge and charge periods for the Option 2 systems.

\begin{tabular}{cccc} 
& $\begin{array}{c}\text { Battery Discharge/ } \\
\text { Fuel Cell }\end{array}$ & $\begin{array}{c}\text { Battery Charge } \\
\text { Year }\end{array}$ & $\begin{array}{c}\text { Electrolyzer } \\
\text { Operating Time (hr) }\end{array}$ \\
\hline 2020 & 1026 & 290 & 544 \\
2021 & 1036 & 315 & 589 \\
2022 & 1032 & 338 & 630 \\
2023 & 1019 & 360 & 669 \\
2024 & 1044 & 398 & 739 \\
2025 & 1043 & 431 & 798 \\
2026 & 1036 & 466 & 859 \\
2027 & 1026 & 503 & 924 \\
2028 & 1014 & 543 & 995 \\
2029 & 1039 & 611 & 1116 \\
\hline Total & 10315 & 4255 & 7863
\end{tabular}

cell operation, the total operating time of greater than 10,000 hours is high compared to existing systems. This may either require technology development and/or delivery of additional modules as replacement units. The battery charge operating time estimate is lower than the electrolyzer operating time, due to the lower system efficiency of the RFC system. Beyond delivering more modules, the electrolyzer (or battery charge) operating life requirement could be reduced by adding more solar array power, though this may also increase the size of the electrolyzer.

Another consideration is calendar life. The energy storage portion of the system only operates for about $17-20 \%$ of the entire decade if both charging and discharging are included. The system is still exposed on the lunar surface for the remainder of the time. This idle period may also have implications for system design and sparing approaches.

\section{Sensitivity Analysis}

Much of the approach in this paper is an attempt to capture the primary effects of different system designs with simplified models. One technique to mitigate some of the uncertainty from the models is a sensitivity analysis of some of the most important variables. This approach can also capture the effect of new technology such as a higher solar cell efficiency. It can also capture the relative risk of a uncertain estimate such as the mass fraction of the fluid tanks. 
This sensitivity analysis studies the effect of a $\pm 10 \%$ variation on the variables shown in Table 4 . The results are shown in Figs. 19 and 20. The baseline cases for the battery- and RFC-based systems are both Option 2 in Tables 1 and 2, respectively. Some of the most sensitive variables for both systems include

Table 4. Variables used for sensitivity analysis.

\begin{tabular}{cc} 
Variable & Symbol, if applicable \\
\hline Solar Array Temperature & $T_{o p}$ \\
Solar Array Dust Loss & \\
Solar Array Radiation loss & \\
Solar Array Voltage & $V_{m p}$ \\
Battery Degradation & \\
DC-DC Converter Efficiency & \\
Switching Unit Efficiency & $\bar{m}_{\text {array }}$ \\
Solar Array Mass per Area & \\
Battery Specific Energy & \\
Maximum Battery Depth-of-Discharge & $V_{\text {cell }}$ \\
Fuel Cell Voltage & $V_{\text {cell }}$ \\
Electrolyzer Voltage & \\
RFC Ancillary Power & \\
RFC Degradation & $m f_{H_{2}}$ \\
Hydrogen Mass Fraction & $m f_{O_{2}}$ \\
Oxygen Mass Fraction & \\
Maximum RFC Depth-of-Discharge &
\end{tabular}

the switching unit efficiency and energy storage depth-of-discharge. The RFC sensitivities appear to be less than the battery case because the RFC system is more diversified in component mass. The battery specific energy is important, but for the RFC, several components including the fluid tanks and fuel cell subsystem significantly impact the overall mass. The switching unit efficiency is important because it imparts a loss to the energy storage system during both charging and discharging periods. The DC-DC converter is not as sensitive because it only affects the solar array power to the loads and to charging the energy storage system. The solar array efficiency (through $\mathrm{V}_{m p}$ ) is an important variable because of the effect of higher solar array power on the energy storage size explained above.

\section{Conclusion}

Comparing Tables 1 and 2, even with significantly oversized solar arrays, the battery subsystem is heavier than a reasonably-sized solar array/RFC combination. However, system mass is only one figure-of-merit, others include life, reliability, and flight experience, for example. This analysis is also based on fixed load requirements and a single location. Other requirements and locations may change the outcome.

Beyond the mass comparison, this work identifies a relatively low number of cycles and overall depth-ofdischarge profile for both batteries and RFCs. Note that this result is for a stationary system; a mobile system would most likely have a much higher number of cycles and average depth-of-discharge. The operational life for the RFC and battery systems in this application are shown to be significant if expected to operate for the entire decade. This requirement can be mitigated by delivering additional modules throughout the decade, at the expense of additional mass needing to be delivered to the surface.

This paper also emphasizes the importance of PMAD component efficiency and the need for well-designed interfaces between the different subsystems. In addition, the solar array size also has a significant impact on energy storage because of the importance of fully recharging before the next shadowed period. This implies that the solar arrays will most likely be required to produce much more power than just the daytime requirement. 


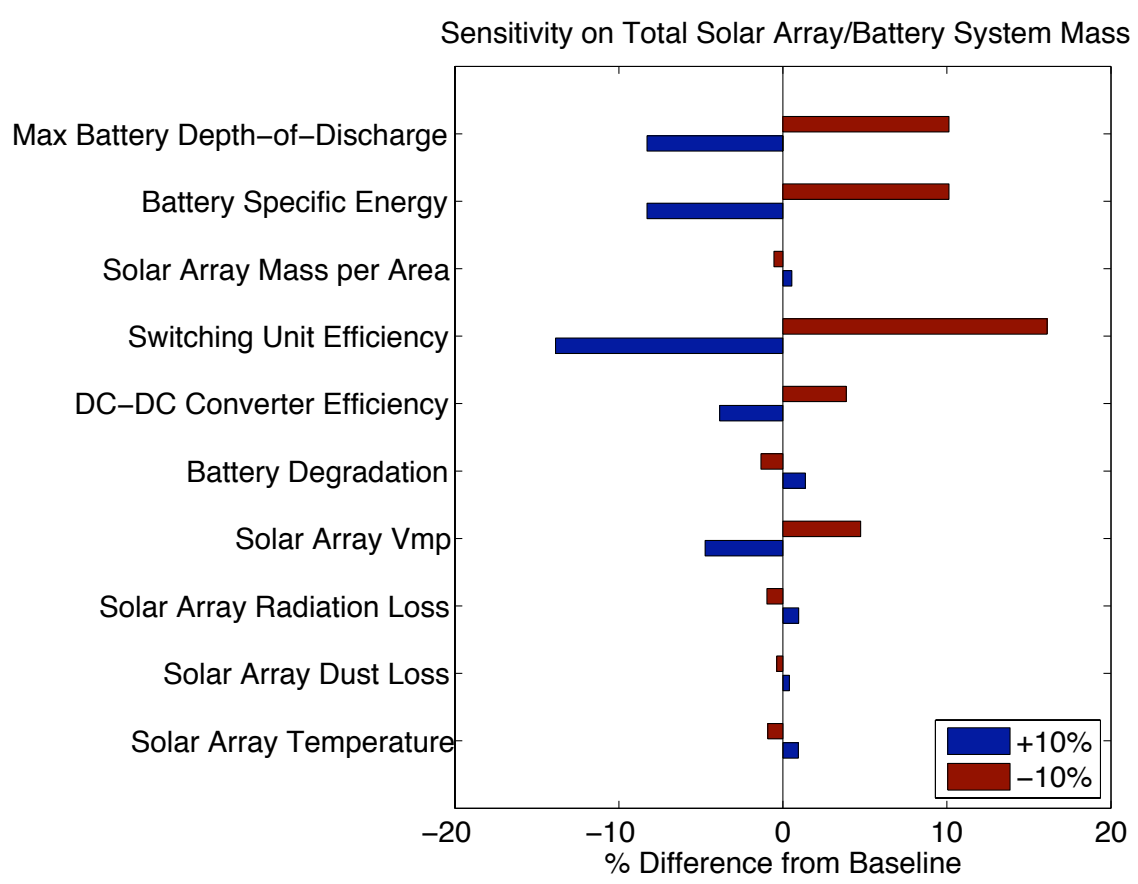

Figure 19. Sensitivity of solar array/battery system variables on total solar array/battery system mass. The baseline case is Option 2 of Table 1 .

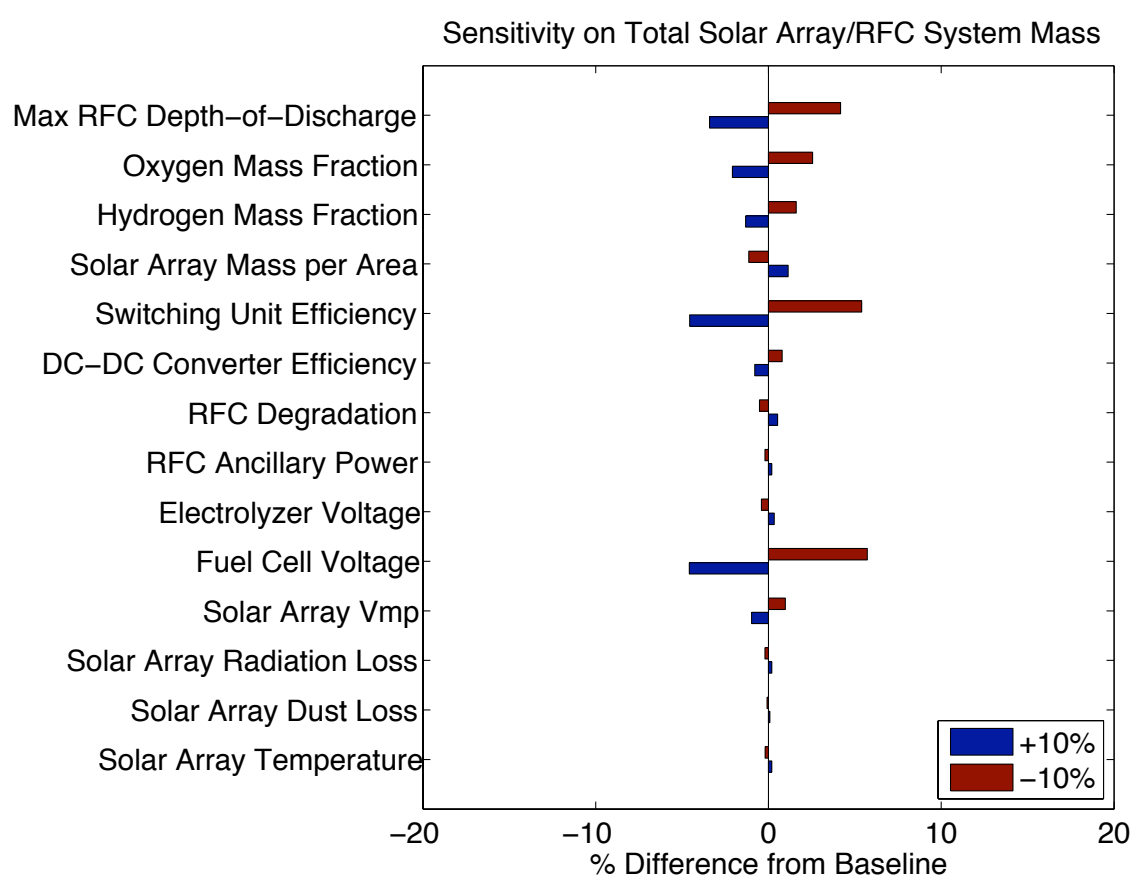

Figure 20. Sensitivity of solar array/RFC system variables on total solar array/RFC system mass. The baseline case is Option 2 of Table 2. 


\section{References}

${ }^{1}$ Rauschenbach, H. S., Solar Cell Array Design Handbook: The Principles and Technology of Photovoltaic Energy Conversion, Van Nostrand, 1980.

${ }^{2}$ Speech by President George W. Bush, January 14, 2004, available at http://www.whitehouse.gov/news/releases/2004/01/200401143.html.

3"NASA's Exploration Architecture Study," NASA-TM-2005-214062, 2005.

${ }^{4}$ NASA Press Release 06-061, 2006.

${ }^{5}$ Session 90-STSA-20, AIAA Space 2007, 2007.

${ }^{6}$ Toups, L., Kennedy, K.J., Tri, T., Smitherman, D., Dorsey, J., "Lunar Architecture Team-Phase 2 Architecture Option-2 Habitation Concepts." ASCE Earth \& Space Conference 2008, 2008.

${ }^{7}$ Toups, L., Kennedy, K.J., Gershman, R., Wilcox, B., Dorsey, J., "Lunar Architecture Team-Phase 2 Architecture Option4 Habitation Concepts." ASCE Earth \& Space Conference 2008, 2008.

${ }^{8}$ NASA Press Release 08-155, 2008.

${ }^{9}$ Toups, L., Kennedy, K.J., et al., "Constellation Architecture Team-Lunar Habitation Concepts," AIAA Space 2008, AIAA-2008-7633, 2008.

${ }^{10}$ NASA Press Release 08-171, 2008.

${ }^{11}$ Apollo 17 Mission Report, NASA Document JSC-07904, 1973.

${ }^{12}$ Fincannon, H. J., "Lunar South Pole Illumination: Review, Reassessment and Power System Implications," 5th International Energy Conversion Engineering Conference, AIAA 2007-4700, 2007.

${ }^{13}$ Fincannon, H. J., "Characterization of Lunar Polar Illumination from a Power System Perspective," 46th AIAA Aerospace Sciences Meeting and Exhibit, AIAA 2008-447, 2008.

${ }^{14}$ Fincannon, H. J., "Lunar Polar Illumination for Power Analysis," 6th International Energy Conversion Engineering Conference, AIAA 2008-5631, 2008.

${ }^{15}$ Emcore Product Brief, available at http://www.emcore.com/assets/photovoltaics/Emcore_BTJ_DS_May_07.pdf, 2007.

${ }^{16}$ Cloud, J. D., Mc Intyre, W. B., Van Horne, T. B., "Surveyor spacecraft system - Surveyor 6 flight performance Final report," NASA CR-93495, 1968.

${ }^{17}$ Larminie, J., Dicks, A., Fuel Cells Systems Explained, John Wiley \& Sons, Ltd., 2003.

${ }^{18}$ Burke, K.A., "Fuel Cells For Space Science Applications," NASA TM-2003-212730, 2003.

${ }^{19}$ NSTS Shuttle Reference Manual, Electrical Power System Section, NASA Document, 1988. 


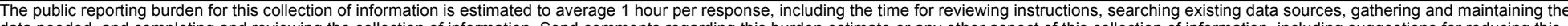

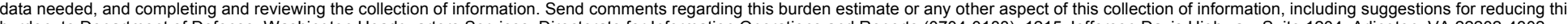

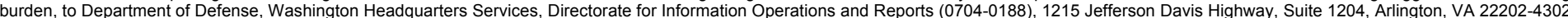

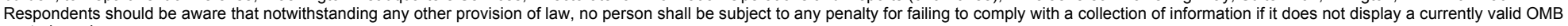
control number.

control number.
PLEASE DO NOT RETURN YOUR FORM TO THE ABOVE ADDRESS

\section{REPORT DATE $(D D-M M-Y Y Y Y)$ \\ 2. REPORT TYPE \\ 3. DATES COVERED (From - To)}

01-03-2009

\section{TITLE AND SUBTITLE}

Technical Memorandum

Analysis of Stationary, Photovoltaic-Based Surface Power System Designs at the Lunar South

Pole

\section{5a. CONTRACT NUMBER}

5b. GRANT NUMBER

5c. PROGRAM ELEMENT NUMBER

\section{AUTHOR(S)}

Freeh, Joshua, E.

\section{5d. PROJECT NUMBER}

5e. TASK NUMBER

5f. WORK UNIT NUMBER

WBS 342806.06.03.03

\section{PERFORMING ORGANIZATION REPORT NUMBER}

E-16669

National Aeronautics and Space Administration

John H. Glenn Research Center at Lewis Field

Cleveland, Ohio 44135-3191

9. SPONSORING/MONITORING AGENCY NAME(S) AND ADDRESS(ES)

National Aeronautics and Space Administration

Washington, DC 20546-0001

\section{DISTRIBUTION/AVAILABILITY STATEMENT}

Unclassified-Unlimited

Subject Categories: 44, 66, 20, and 91

Available electronically at http://gltrs.grc.nasa.gov

This publication is available from the NASA Center for AeroSpace Information, 301-621-0390

\section{SPONSORING/MONITORS ACRONYM(S) \\ NASA \\ 11. SPONSORING/MONITORING REPORT NUMBER \\ NASA/TM-2009-215506; AIAA-2008- 7810}

\section{SUPPLEMENTARY NOTES}

\section{ABSTRACT}

Combinations of solar arrays and either batteries or regenerative fuel cells are analyzed for a surface power system module at the lunar south pole. The systems are required to produce $5 \mathrm{~kW}$ of net electrical power in sunlight and $2 \mathrm{~kW}$ of net electrical power during lunar night periods for a 10-year period between 2020 and 2030. Systems-level models for energy conservation, performance, degradation, and mass are used to compare to various systems. The sensitivities of important and/or uncertain variables including battery specific energy, fuel cell operating voltage, and DC-DC converter efficiency are compared to better understand the system. Switching unit efficiency, battery specific energy, and fuel cell operating voltage appear to be important system-level variables for this system. With reasonably sized solar arrays, the regenerative fuel cell system has significantly lower mass than the battery system based on the requirements and assumptions made herein. The total operational time is estimated at about $10,000 \mathrm{hr}$ in battery discharge/fuel cell mode and about 4,000 and $8,000 \mathrm{hr}$ for the battery charge and electrolyzer modes, respectively. The estimated number of significant depth-of-discharge cycles for either energy storage system is less than 100 for the 10-year period.

15. SUBJECT TERMS

Solar arrays; Fuel cells; Electric batteries; Moon; Lunar base

\begin{tabular}{|c|c|c|c|}
\hline \multicolumn{3}{|c|}{ 16. SECURITY CLASSIFICATION OF: } & \multirow{2}{*}{$\begin{array}{l}\text { 17. LIMITATION OF } \\
\text { ABSTRACT } \\
\text { UU }\end{array}$} \\
\hline $\begin{array}{l}\text { a. REPORT } \\
\text { U }\end{array}$ & $\begin{array}{l}\text { b. ABSTRACT } \\
U\end{array}$ & $\begin{array}{l}\text { c. THIS } \\
\text { PAGE } \\
\text { U }\end{array}$ & \\
\hline
\end{tabular}

18. NUMBER
OF
PAGES
25

19a. NAME OF RESPONSIBLE PERSON
STI Help Desk (email:help@sti.nasa.gov)
19b. TELEPHONE NUMBER (include area code)
301-621-0390

Standard Form 298 (Rev. 8-98)

Prescribed by ANSI Std. Z39-18 

